\section{Concord Still Going Up}

Tine Public Accounts Committee of the House of Commons is in particularly good form at the moment. Not content with its recent report on Bristol-Siddeley engine contracts, it has now published a report detailing other examples of overcharging. Almost inevitably, one of the things which the report reveals is that the cost of Concord has gone up again, despite the fact that the last estimate of $£ 500$ million contained no less than $£ 50$ million for "contingencies". The extra figure this time is $£ 28$ million, which the Ministry of Technology had apparently forgotten to include-it represents an allowance for spending at the ministry's own laboratories. The committee also criticizes the agreement between France and Britain on intramural expenses, which was "ambiguous".

The committee also suggests that other contracts have been agreed at prices favourable to the companies involved. In particular, the price of Buccaneer aircraft was too high, and the committee notes that Hawker-Siddeley have now agreed to repay any profits over the figure of 17.5 per cent on costs; it does not, however, reveal how much this is.

\section{Organizing Aid}

Wнат is the best way of distributing aid given for the general economic development of the poorer countries of the world ? The problem of a strategy for aid-giving is dealt with by a recent publication of the Overseas Development Institute, called Pledged to Development, and written by John White, a research member of the Institute.

Previous studies by the institute have revealed wide divergences in the motivation, administration and financial charactcristics of the different aid programmes, as well as in the approach of the aid-giving countries to the fundamental questions of the nature of economic aid. A further study of a single aid-receiving country -Uganda-showed that these divergences can give rise to practical problems. Not only is there a loss in efficiency when donors are dealing with different problems in the same undeveloped country-more fundamentally, a successful aid programme must deal with the whole economy, over a long period of time. Since very few donors are prepared to take on this kind of project, even for a small underdeveloped country, consortia or consultative groups of donors must be formed. In 1958 the Indian Consortium was formed, and in the next few years similar groups were formed for Pakistan, Greece and Turkey. For a number of other countries consultative groups were set up, which differ from consortia in that the countries contributing are asked to make no specific financial pledge to the development programme.

It is with these groups and the strategy of aid that the book deals. The word "strategy" is one used by the author. It reflects his view that future operations of the group will require more than co-operation between the various members; a joint command is needed, delegating authority to the countries coneerned. For this an international organization with some degree of operational autonomy is required.

This point, and other questions of the mechanism of the group, are disenssed in the light of two earlier chapters which are ease histories of the Pakistan
Consortium and the Turkish Consortium, respectively the most and the least successful of the consortia so far formed. Mr White's conclusions as to the nature of the groups and how they should work differ in some respects to the views of the World Bank, the agency responsible for the largest number of aid groups.

As he points out, the original aim of the aid-giving countries in the late $1950 \mathrm{~s}$ was to raise the standard of living of all the poorer parts of the world to a tolerable level. For various reasons this soon declined into a situation in which aid was given to only a few countries. Perhaps the groups envisaged by $\mathrm{Mr}$ White will be more successful in dealing with the critically important problem of world hunger.

\section{More for NRDC}

THE National Research Development Corporation has nearly spent the $£ 25$ million that it has been entitled to borrow from the Ministry of Technology. Because of this, the Minister, Mr Anthony Wedgwood Benn, will introduce legislation to increase the limit of the advances that may be made by the ministry to the corporation. The ceiling of the corporation's borrowing powers was last raised, in June 1965, from $£ 10$ million to $£ 25$ million. Mr Benn's legislation, which will double the amount to $£ 50$ million, can be expected to pass through Parliament early next year.

Though the corporation's income from licence receipts has been increasing consistently since 1962, it will continue to depend on loans from the ministry for a long time. The loan of 1966 alone far exceeded the earnings of the corporation over the previous 31 months. But increasing the power to borrow is the clearest way to solvency for the corporation. Backing research projects for profit is, like any other stochastic process, more likely to be successful the greater the scale of operations.

\section{Instruments under Pressure}

SUPERfictalisy, the annual report of the Scientific Instrument Manufacturers' Association for 1966-67 makes moderately happy reading-overall production is up by 4.7 per cent, above the chancellor's target growth rate of 3 per cent, and export sales are up by $9 \cdot 1$ per cent. When, however, the figures are compared with those for the previous five years, 1960-65, things do not look so bright-in that period there was an annual increase in production of 12 per cent. This setback can be attributed mainly to the "freeze", because production in the first half of 1966 rose by 11 per cent compared with 1965 , while in the third quarter it rose by only 3 per cent and in the last quarter it fell by 5 per cent.

Although exports were up $9 \cdot 1$ per cent, imports were also up, and by a greater percentage. At the present moment, there is a favourable balance of payments in this industry, but unless imports slow down or exports speed up, imports can bc expected to overtake exports within the next four or five years. The present drop in overall world trade and the tariff cuts agreed in the Kennedy Round which will slowly come into force over the next five years will do nothing to help the industry's position.

The scientific instrument industry in Britain is well protected behind some relatively high tariff barriers, 